\title{
OPEN Author Correction: CRISPR/Cas9 microinjection in oocytes disables pancreas development in sheep
}

Marcela Vilarino, Sheikh Tamir Rashid, Fabian Patrik Suchy, Bret Roberts McNabb, Talitha van der Meulen, Eli J. Fine, Syed Daniyal Ahsan, Nurlybek Mursaliyev, Vittorio Sebastiano, Santiago Sain Diab, Mark O. Huising, Hiromitsu Nakauchi \& Pablo J. Ross

Correction to: Scientific Reports https://doi.org/10.1038/s41598-017-17805-0, published online 12 December 2017

The original version of this Article contained an error in the spelling of the author Syed Daniyal Ahsan, which was incorrectly given as Syed Ahsan. This has now been corrected in the PDF and HTML versions of the Article.

(c) (i) Open Access This article is licensed under a Creative Commons Attribution 4.0 International cc) License, which permits use, sharing, adaptation, distribution and reproduction in any medium or format, as long as you give appropriate credit to the original author(s) and the source, provide a link to the Creative Commons license, and indicate if changes were made. The images or other third party material in this article are included in the article's Creative Commons license, unless indicated otherwise in a credit line to the material. If material is not included in the article's Creative Commons license and your intended use is not permitted by statutory regulation or exceeds the permitted use, you will need to obtain permission directly from the copyright holder. To view a copy of this license, visit http://creativecommons.org/licenses/by/4.0/.

(c) The Author(s) 2020 